\title{
Phenol-based Extraction of RNA from Chlamydomonas reinhardtii
}

Emanuel Sanz-Luque ${ }^{1, *}$ and Amaury de Montaigu ${ }^{2}$

${ }^{1}$ Department of Plant Biology, Carnegie Institution for Science, Stanford, CA, USA; ${ }^{2}$ Institute of Quantitative Genetics and Genomics of Plants, University of Dusseldorf, Dusseldorf, Germany

*For correspondence: esanzluque@carnegiescience.edu

[Abstract] RNA extraction is a basic procedure in molecular biology and a wide variety of commercial kits are available. Some of these kits have been successfully used in Chlamydomonas. However, in some cases RNA quality and quantity may be dramatically reduced depending on the strains and/or the conditions where cells were grown or treated. Phenol-based protocols are the most robust methods to obtain both high quantity and quality RNA from any strain of this alga grown in any condition. Here, we describe an easy and cheap protocol using phenol but avoiding the acute toxicity of guanidine isothiocyanate present in the commercial phenol-based mixtures.

Keywords: RNA, DNase treatment, Phenol extraction, Chlamydomonas

\section{Materials and Reagents}

1. Gloves

2. Pipette tips

3. $2 \mathrm{ml}$ microcentrifuge tubes

4. Liquid nitrogen $\left(\mathrm{N}_{2}\right)$

5. SDS $20 \%$

6. Water-saturated Phenol ( $\mathrm{pH}$ 4.5) (Amresco, catalog number: 0981-400ML)

7. Chloroform:Isoamyl Alcohol (24:1) (Amresco, catalog number: X205-450ML)

8. Chloroform (Sigma-Aldrich, catalog number: 372978) (store at $4{ }^{\circ} \mathrm{C}$ )

9. $8 \mathrm{M}$ Lithium Chloride $\left(\mathrm{LiCl}\right.$, store at $\left.4{ }^{\circ} \mathrm{C}\right)$

10. $70 \%$ and $100 \%$ ethanol (store at $4{ }^{\circ} \mathrm{C}$ )

11. Nuclease-free water

12. TURBO $^{\mathrm{TM}}$ DNase (Thermo Fisher Scientific, Invitrogen ${ }^{\mathrm{TM}}$, catalog number: AM2238)

13. $3 \mathrm{M}$ Sodium Acetate

14. Agarose

15. Extraction Buffer (see Recipes)

16. Phenol ( $\mathrm{pH}$ 4.5):Chloroform:Isoamyl Alcohol (see Recipes) (store at $4{ }^{\circ} \mathrm{C}$ )

\section{Equipment}

\section{Pipettes}


2. Autoclave

3. Centrifuge

4. Nanodrop (Thermo Fisher Scientific, model: NanoDrop ${ }^{\mathrm{TM}}$ 1000, catalog number: ND-1000)

\section{Procedure}

A. Cell extract preparation

1. Collect $10 \times 10^{6}$ to $25 \times 10^{6}$ cells by centrifugation at $2,000 \times$ g. At this point the pellet can be frozen in liquid $\mathrm{N}_{2}$ and stored at $-80^{\circ} \mathrm{C}$.

2. Resuspend the pellet in $900 \mu \mathrm{l}$ of Extraction Buffer (see Recipes) and transfer the volume to 2 $\mathrm{ml}$ microcentrifuge tubes. Keep tubes on ice during the entire procedure.

3. Add $100 \mu \mathrm{l}$ of SDS $20 \%$.

4. Mix by inversion 3-4 times and incubate for $5 \mathrm{~min}$ on ice. Cell extracts can be frozen at this step in liquid $\mathrm{N}_{2}$.

B. Nucleic acids extraction

1. Add 1 volume $(1 \mathrm{ml})$ of Phenol $(\mathrm{pH} \mathrm{4.5):Chloroform:Isoamyl} \mathrm{alcohol} \mathrm{(see} \mathrm{Recipes)} \mathrm{and} \mathrm{vortex}$ for $1 \mathrm{~min}$ (be sure that the aqueous and organic phases are properly mixed).

2. Centrifuge for $15 \mathrm{~min}$ at $>18,000 \times \mathrm{g}$. Centrifugation yields three main phases, the lower organic phase containing proteins and small fragments of DNA, a white interphase where some proteins and large DNA fragments remain and the upper aqueous phase that retains most of the RNA and some contaminant DNA that will be eliminated later on.

3. Transfer as much aqueous phase as possible to a $2 \mathrm{ml}$ clean tube without aspiring the interphase.

4. Use the aqueous phase to repeat extraction from Step B1 until interphase disappears as shown in Figure 1 (usually one or two more extractions).

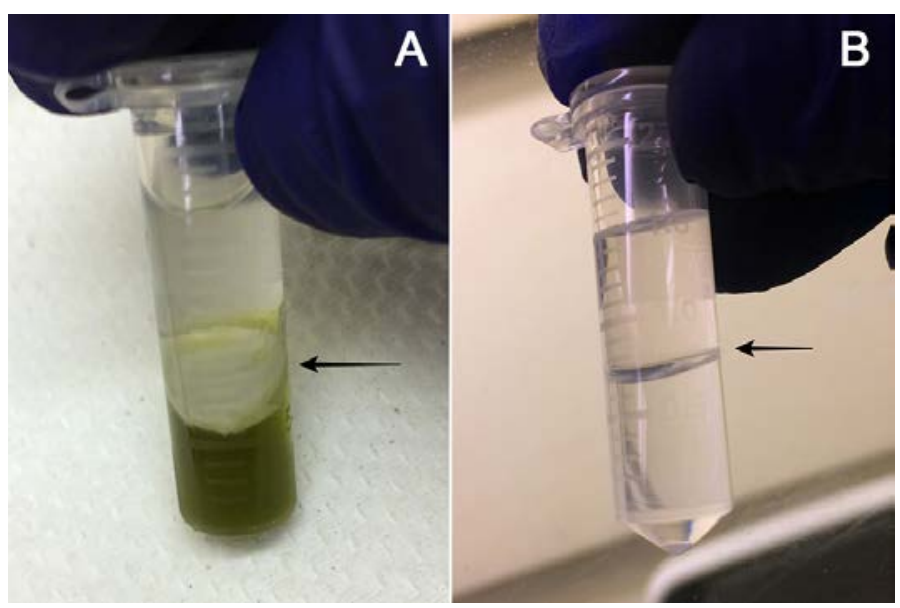

Figure 1. Interphase after the first and third extraction steps. A. The arrow indicates the white interphase after the first extraction. B. After the third extraction, the interphase has 
completely disappeared.

5. When interphase disappears, transfer the aqueous phase to a new tube and add 1 volume of water-saturated Chloroform and vortex for 1 min. Remaining phenol is eliminated in this step.

6. Centrifuge for $5 \mathrm{~min}$ at $>18,000 \times g$ and transfer the aqueous phase to a clean tube.

C. RNA precipitation

1. Add 1 volume of $8 \mathrm{M} \mathrm{LiCl}$ to the aqueous phase from step B6 and incubate for $4 \mathrm{~h}$ at $4{ }^{\circ} \mathrm{C}$. Overnight incubation is recommended when maximum efficiency is required.

2. Centrifuge for $20 \mathrm{~min}$ at $>18,000 \times g$ at $4^{\circ} \mathrm{C}$.

3. Discard supernatant by decanting and wash the pellet with $70 \%$ ethanol.

4. Centrifuge for $5 \mathrm{~min}$ at $>18,000 \times \mathrm{g}$.

5. Discard the ethanol by decanting, eliminate the traces of ethanol by pipetting and air-dry the pellet in a hood for $10 \mathrm{~min}$.

6. Resuspend in $50 \mu \mathrm{l}$ of nuclease-free $\mathrm{H}_{2} \mathrm{O}$ (at this point RNA can be stored at $-80{ }^{\circ} \mathrm{C}$ ).

7. Quantify nucleic acids by optical density at $260 / 280$ (we use Nanodrop ND-1000 from Thermo Fisher Scientific). The ratio of 260/280 should be in the range of 2-2.2.

D. Removal of contaminating genomic DNA

1. Use $10 \mu \mathrm{g}$ of RNA in a $50 \mu \mathrm{l}$ final volume reaction with 2 units of TURBO ${ }^{\mathrm{TM}}$ DNase $(1 \mu \mathrm{l})$ and 5 $\mu$ of 10X TURBO DNase Buffer and incubate at $37^{\circ} \mathrm{C}$ for $1 \mathrm{~h}$.

2. Add $450 \mu \mathrm{l}$ of nuclease-free $\mathrm{H}_{2} \mathrm{O}$ and remove DNase by adding 1 volume (500 $\left.\mu \mathrm{l}\right)$ of Chloroform:Isoamyl alcohol (24:1).

3. Vortex for $1 \mathrm{~min}$ and centrifuge for $10 \mathrm{~min}$ at $>18,000 \times \mathrm{g}$.

4. Transfer the aqueous phase (RNA) to a clean tube and add 2.5 volumes of $100 \%$ ethanol and 0.1 volume of $3 \mathrm{M}$ sodium acetate and incubate for $1 \mathrm{~h}$ at $-20^{\circ} \mathrm{C}$.

5. Centrifuge for $30 \mathrm{~min}$ at $>18,000 \times g, 4^{\circ} \mathrm{C}$.

6. Discard $100 \%$ ethanol and add $300 \mu \mathrm{l}$ of $70 \%$ ethanol to wash any residual salt away and partially hydrate the pellet. Incubate for $5 \mathrm{~min}$ on ice and centrifuge for $10 \mathrm{~min}$ at $4{ }^{\circ} \mathrm{C}$.

7. Remove the $70 \%$ ethanol by decanting, eliminate the traces of ethanol by pipetting and air-dry the pellet in a hood for $5 \mathrm{~min}$.

8. Resuspend in $25 \mu \mathrm{l}$ of nuclease-free $\mathrm{H}_{2} \mathrm{O}$.

9. Quantify RNA. The ratio of $260 / 280$ should be between 2 and 2.2 (2 is accepted as 'pure' RNA).

10. Check the RNA integrity by electrophoresis (Figure 2). Load $0.5-1 \mu \mathrm{g}$ in fresh $1 \%$ agarose gel. 


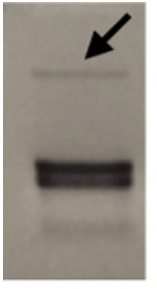

1

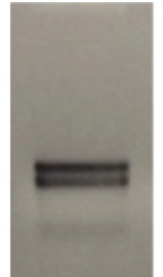

2

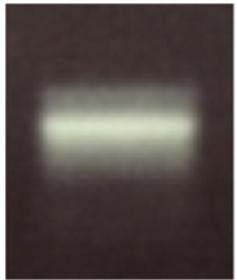

3

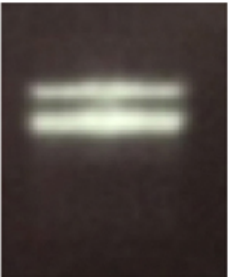

4

Figure 2. RNA agarose gel. Lane 1 shows a sample before DNase treatment. gDNA is indicated with the arrow. Lane 2 shows the same sample after DNase treatment. Lane 3 corresponds to a sample partially degraded and lane 4 is a sample for the same extraction without degradation. Two discrete bands of ribosomal RNA are indicative of no significant degradation. These two bands can be checked by loading 0.5 to $1 \mu \mathrm{g}$ of total RNA in $1 \%$ agarose gel and then run electrophoresis.

\section{$\underline{\text { Notes }}$}

1. To avoid RNA degradation, wear gloves and use nuclease-free $\mathrm{H}_{2} \mathrm{O}$, tubes and tips. Although it is not required, all solutions can be prepared using DEPC treated $\mathrm{H}_{2} \mathrm{O}$ that inhibits RNase activity. We recommend to autoclave all solutions to reduce the contaminant RNase activity.

2. Phenol is toxic and corrosive, and should be handled in a fume hood.

\section{$\underline{\text { Recipes }}$}

1. Extraction Buffer

Mix $100 \mathrm{mM}$ Tris- $\mathrm{HCl}$, pH 8 with $400 \mathrm{mM} \mathrm{NaCl}$ and $50 \mathrm{mM}$ EDTA pH 8 and autoclave

2. Phenol ( $\mathrm{pH} 4.5)$ :Chloroform:Isoamyl Alcohol

Mix 1 volume of water-saturated Phenol pH 4.5 with 1 volume of Chloroform:Isoamyl alcohol $24: 1$

Keep this solution at $4{ }^{\circ} \mathrm{C}$

\section{Acknowledgments}

E. S-L. thanks the funding received from the European Union's Horizon 2020 research and innovation programme under the Marie Sklodowska-Curie agreement No.751039. This protocol was adapted and modified from Schloss et al. (1984) and used in de Montaigu et al. (2010) and Sanz-Luque et al. (2016).

\section{$\underline{\text { References }}$}

1. de Montaigu, A., Sanz-Luque, E., Galvan, A. and Fernandez, E. (2010). A soluble guanylate 
cyclase mediates negative signaling by ammonium on expression of nitrate reductase in Chlamydomonas. Plant Cell 22(5): 1532-1548.

2. Sanz-Luque, E., Ocaña-Calahorro, F., Galvan, A., Fernandez, E. and de Montaigu, A. (2016). Characterization of a mutant deficient for ammonium and nitric oxide signalling in the model system Chlamydomonas reinhardtii. PLoS One 11(5): e0155128.

3. Schloss, J. A., Silflow, C. D. and Rosenbaum, J. L. (1984). mRNA abundance changes during flagellar regeneration in Chlamydomonas reinhardtii. Mol Cell Biol 4(3): 424-434. 